\title{
PENGARUH MENDENGARKAN ASMAUL HUSNA TERHADAP MUAL MUNTAH PADA IBU HAMIL
}

The Effect Of Listening To Asmaul Husna On Vomiting Nausea In Pregnant Women

\author{
Ratih Marlina, Nur Rakhmawati, Setiyawan \\ Pengajar Universitas Kusuma Husada Surakarta (nurrakhmawati_ikmuns@yahoo.co.id)
}

\begin{abstract}
Background: Pregnancy affects the body's system, both hormonally, physically, and psychologically. Nausea that is sometimes accompanied by vomiting usually arises from the age of 5 weeks, which is calculated based on the first day at the last and reaches the peak at 8 weeks to 12 weeks and ends at 16 to 18 weeks. Nausea and vomiting in pregnancy is the reaction of the pregnant woman's body to changes that occur as a result of pregnancy.

Objective: This study is to find out the effect of asmaul husna therapy on vomiting nausea in pregnant women.

Methods: This research was conducted on 16 respondents using quasy experiment research method with Pre Test and Post Test Without Control Group approach. Sampling is done on a non probability sampling with purposive sampling technique. Data analysis in this study using wilcoxon test. The population of this study is pregnant women total 16 respondents.

Results: There is therapy listening to Asmaul Husna terhadap nausea vomiting in pregnant women is $p$ value of $0,000<0.0$.

Conclusion: This study is the effect of Asmaul Husna listening therapy on vomiting nausea in pregnant women.
\end{abstract}

Keywords :Asmaul Husna; Pregnant Women; Vomiting Nausea

\begin{abstract}
ABSTRAK
Latar Belakang: Kehamilan memengaruhi sistem tubuh, baik secara hormonal, fisik, maupun psikologi. Mual yang terkadang disertai muntah biasanya timbul sejak usia gestasi 5 minggu, yang dihitung berdasarkan hari pertama pada terakhir dan mencapai puncak pada usia 8 minggu hingga 12 minggu serta berakhir pada usia 16 hingga 18 minggu. Mual muntah gejala pertama yang dialami ibu hamil yang sering terjadi sebelum mengalami menstruasi pertama tidak datang.

Tujuan: Penelitian ini bertujuan untuk mengetahui pengaruh pemberian terapi mendengarkan Asmaul Husna terhadap mual muntah pada ibu hamil.

Metode: Penelitian ini merupakan Quasy Experiment dengan pendekatan Pre Test and Post Test Without Control Group. Pengambilan sampel dilakukan secara non probability sampling dengan teknik purposive sampling. Populasi penelitian ini adalah ibu hamil trimester pertama di wilayah Puskesmas Sidoharjo Sragen sejumlah 16 orang. Analisis data dalam penelitian ini menggunakan uji Wilcoxon.
\end{abstract}

Hasil: Ada pengaruh terapi mendengarkan Asmaul Husna terhadap mual muntah pada ibu hamil dengan nilai $p$ value $0,000<0,05$.

Kesimpulan: Ada pengaruh terapi mendengarkan Asmaul Husna terhadap mual muntah pada ibu hamil.

Kata Kunci :Asmaul Husna; Ibu hamil; Mual Muntah 


\section{LATAR BELAKANG}

Kehamilan memengaruhi sistem tubuh, baik secara hormonal, fisik, maupun psikologi. Mual yang terkadang disertai muntah biasanya timbul sejak usia gestasi 5 minggu, yang dihitung berdasarkan hari pertama pada terakhir dan mencapai puncak pada usia 8 minggu hingga 12 minggu serta berakhir pada usia 16 hingga 18 minggu (Tiran, 2013).

Mual muntah gejala pertama yang dialami ibu hamil yang sering terjadi sebelum periode menstruasi pertama tidak datang. Mual dan muntah pada kehamilan merupakan reaksi tubuh ibu hamil terhadap perubahan yang terjadi akibat kehamilan (Trottier, 2012).

Mual muntah akibat dari meningkatnya kadar estrogen, oleh karena keluhan ini terjadi pada trimester pertama. Pengaruh fisiologis hormon estrogen ini tidak jelas, mungkin berasal dari sistem saraf pusat atau akibat berkurangnya pengosongan lambung. Awal kehamilan yang merupakan komplikasi mual muntah pada ibu hamil, bila terjadi terus menerus dapat bermasalah dehidrasi dan tidak imbangnya elektrolit dengan alkalosis hipokloremik (Soejoenes, 2014). Mual (nausea) dan muntah (emesis gravidarum) adalah gejala yang sering terjadi pada 60-80 \% primigravida dan 40-60 \% multigravida berdasarkan Profil Kesehatan Indonesia 2017 (Depkes, 2017).

Faktor-faktor yang menyebabkan mual muntah prevelansi yaitu seperti situasi korpus luteum sisi kanan menyebabkan tingginya kadar hormon steroid di dalam sistem porta hepatik, perubahan karbohidrat dan metabolisme lemak, dampak pada kemampuan mencium dan melihat, faktor genetik, hormon Human Chorionic Gonadotropin (HCG), faktor imunologis, hormon estrogen dan progesteron. Faktor predisposisi mual dan muntah pada kehamilan dapat dikaitkan dengan perilaku, dukungan, keletihan, mual dan muntah dikehamilan sebelumnya, merokok, masalah sosio-ekonomi, kesulitan dalam masalah membina hubungan, dan psikologis (Tiran, 2015).

Dampak mual muntah jika tidak ditangani dengan baik akan berlanjut menjadi hyperemesis gravidarum atau mual muntah yang berlebihan sehingga dapat mengganggu aktivitas sehari-hari dan keadaan ibu hamil menjadi buruk (Tiran, 2015). Dampak yang terjadi pada ibu akibat dari mual dan muntah yaitu menurunnya cairan elektrolit di dalam tubuh ibu, sehingga terjadi hemokonsentrasi yang dapat memperlambat peredaran darah, nafsu makan menurun yang mempengaruhi tumbuh kembang janin, gangguan nutrisi, dehidrasi, kelemahan, dan penurunan berat badan (Marunung, 2011).

Tindakan farmakologis yang sering digunakan untuk menangani mual muntah yaitu dengan melibatkan peresepan antiemetik. Obat - obatan yang dapat membantu mengurangi mual muntah pada ibu hamil yaitu bloker serotonin seperti Ondansentron (mengeblok reseptor serotonin dari CTZ), 
Bloker Dopaminergik seperti Metoklopramid (mengeblok reseptor dopamine dari CTZ), Fenotiasin, Sedative, Steroid, dan Histamine, baik secara tersendiri atau dalam kombinasi (Smeltzer \& Bare, 2011). Tindakan farmakologis tersebut mempunyai efek samping diantaranya penurunan nafsu makan, mual, teremor dan pusing, obat-obatan tersebut mengurangi mual muntah pada ibu hamil berfungsi hanya sesaat 40\%-50\% saja jika minum obat tersebut mual muntah akan muncul kembali (Omoigui, 2014).

Penatalaksanaan secara farmakologis saja tidak lengkap tanpa disertai dengan terapi non farmakologi yaitu dengan terapi sepiritual dan juga sebaliknya, terapi non farmakologi tidak lengkap jika tidak disertai dengan terapi farmakologis (Lukman, 2012). Menurut Fatmawati (2012), penanganan mual muntah pada ibu hamil dilakukan secara non farmakologis dengan cara mempertahankan asupan nutrisi dan cairan pada ibu hamil, sediakan makanan kering seperti biskuit atau roti, jaga pola makan dengan cara makan sedikit-sedikit tapi sering, hindari makanan yang mengandung lemak, dan berminyak, serta berbumbu keras, banyak mengkonsumsi makanan tinggi karbohidrat, banyak minum air, dan mengkonsumsi vitamin B6 yang diimbangi dengan istirahat yang cukup. Perawatan spiritual sesuai ajaran Islam dapat diberikan di Indonesia karena $87.18 \%$ penduduk Indonesia adalah muslim (Badan Pusat Statistik, 2017).

Asmaul Husna dapat digunakan dalam menangani berbagai penyakit, secara aplikatif mendengarkan Asmaul Husna tidak sulit dilakukan, serta mudah dan cepat dilaksanakan. Terapi ini dapat dijadikan terapi pelengkap bagi terapi farmakologi (Lukman, 2013). Salah satu bentuk teknik distraksi yang sering digunakan adalah distraksi pendengaran Asmaul Husna distraksi mendengarkan biasanya dilakukan dengan mendengarkan suara alam atau instruksi meditasi dan juga dapat berupa suara-suara yang mengandung unsur-unsur spiritual sesuai dengan keyakinan yang dianut (Perry \& Potter, 2013).

Rasa nyaman pada ibu hamil tersebut dapat mempengaruhi hormon estrogen dan hal yang dapat berpengaruh menurunkan mual muntah pada ibu hamil (Soejoenes, 2014) Menurut Silverrthon, (2013), Asamaul Husna yang bertugas menghambat aliran impuls dari neuron satu menuju neuron yang lain oleh neurotransmitter dimana sebagai siklus mual muntah pada ibu hamil dapat menenangkan suasana hati lebih tenang.

Berdasarkaan hasil survei pendahuluan yang dilakukan untuk mengetahui mual muntah pada ibu hamil di wilayah Puskesmas Sidoharjo Sragen yang banyak kasus ibu hamil mual muntah. Peneliti melakukan wawancara dan didapatkan ibu hamil trimester pertama yang mengalami kejadian mual muntah ada sejumlah 26 ibu hamil ditrimester pertama. Mayoritas mengatakan gangguan mual muntah 
akan muncul saat aktivitas dan tidak nyaman. Berdasarkan latar belakang yang telah dijelaskan tersebut maka peneliti tertarik untuk melakukan penelitian dengan judul "Pengaruh Mendengarkan Asmaul Husna Terhadap Mual Muntah Pada Ibu Hamil”.

\section{METODE PENELITIAN}

Penelitian ini sudah dilakukan pada bulan Febuari 2020 di desa Sidoharjo Sragen. Jenis penelitian ini yaitu penelitian kuantitatif dan desain yang digunakan adalah quasy ekperiment. Rancangan penelitian yang digunakan adalah dengan pendekatan pre and post test without control grup. Populasi dalam penelitian ini adalah pasien mual muntah pada ibu hamil. Berdasarkan studi pendahuluan jumlah ibu hamil trimester pertama pada bulan Desember 2019 sebanyak 26 pasien. Pengambilan sampel dalam penelitian ini dengan menggunakan non probability.

Dalam penelitian ini variabel idenpenden adalah mendengarkan Asmul Husna. variabel dependen terkait dalam penelitian ini adalah mual muntah pada ibu hamil trimester pertama.

Instrument penelitian ini alat ukur skala Numeric Ranting Scale (NRS) adalah daftar pertanyaan yang sudah tersusun dengan baik, sudah matang, dimana responden (dalam hal angket) tinggal memberikan jawaban atau dengan memberikan tanda-tanda tertentu (Notoatmodjo, 2015)

\section{HASIL DAN PEMBAHASAN}

\section{Hasil Analisa Univariat}

\section{Usia Responden}

Berdasarkan hasil penelitian ini diketahui bahwa umur klien mayoritas responden berusia 26-35 tahun. Hal ini sesuai dengan penelitian yang dilakukan oleh Rinata (2018), bahwa usia yang lebih optimal bagi seorang ibu hamil adalah usia 20-35 tahun karena pada usia tersebut rahim matang dan mampu menerima kehamilan baik ditinjau dari segi psikologi dan fisik.

Pada penelitian yang lain mengatakan bahwa salah satu faktor penyebab tidak langsung kematian ibu adalah terlalu muda melahirkan kurang dari 20 tahun sedangkan melahirkan lebih dari umur 35 tahun juga dapat menyebabkan kematian ibu saat melahirkan (Sukartiningsih, 2012). Menurut peneliti pada penelitian mengatakan bahwa frekuensi terbanyak mual muntah pada usia 25-35 tahun karena kehamilan pada usia tersebut memiliki reproduksi yang sehat dan sistem reproduksi yang matur.

\section{Mual Muntah Sebelum Mendengarkan Asmaul Husna}


Berdasarkan data hasil penelitian dapat diketahui bahwa responden yang mengalami mual muntah trimester pertama sebelum diberi terapi Asmaul Husna mengalami mual muntah berat (7-10 berat). Hal ini sesuai dengan salah satu kriteria diagnostik sesuai penelitian yang dilakukan oleh (Swarihandayanti, 2014), bahwa mual muntah merupakan salah satu ciri yang dialami oleh ibu hamil ditandai dengan skor 0 -10 dimana dikelompokkan yaitu dengan yang pertama skor 0 berarti non atau tidak mual munta, skor 0 -3 dikategorikan mild atau ringan mual muntahnya. skor 4 - 6 dinilai moderate atau mual muntah sedang, skor 7 - 10 yaitu severe yaitu mual muntah dengan skor tertinggi atau terjadi mual muntah. Mual muntah akibat dari meningkatnya kadar estrogen, oleh karena keluhan ini terjadi pada trimester pertama. Pengaruh fisiologis hormon estrogen ini tidak jelas, mungkin berasal dari sistem saraf pusat atau akibat berkurangnya pengosongan lambung.

Menurut Suririnah (2013), hampir 40-90\% dari wanita hamil mengalami mual muntah pada trimester pertama (3 bulan pertama kehamilan). Awal kehamilan yang merupakan komplikasi mual muntah pada ibu hamil, bila terjadi terus menerus dapat bermasalah dehidrasi dan tidak imbangnya elektrolit dengan alkalosis hipokloremik (Soejoenes, 2014). Menurut peneliti tingginya skor mual muntah pada ibu hamil trimester pertama dikarenakan beberapa faktor situasi korpus luteum sisi kanan menyebabkan tingginya kadar hormon steroid di dalam sistem porta hepatik, perubahan karbohidrat dan metabolisme lemak, dampak pada kemampuan mencium dan melihat, faktor genetik, hormon Human Chorionic Gonadotropin (HCG), faktor imunologis, hormon estrogen dan progesterone. Hasil observasi tersebut sesuai dengan hasil penelitian yang didapatkan yang menunjukan bahwa pada kelompok intervensi memiliki skor mual muntah berat, kemungkinan terjadi karena mayoritas responden berusia 26-35 tahun dalam kategori usia dewasa awal sebanyak 9 responden (56,3\%) yang masih memounyai indra penciuman yang sensitif.

\section{Mual Muntah Sesudah Mendengarkan Asmaul Husna}

Berdasarkan hasil peneliti yang sudah diberikan terapi mendengarkan Asamul Husna terjadi penurunan dengan skor responden mual muntah ringan dan sedang memiliki jumlah yang sama sebanyak 8 responden (50\%). Dari hasil penelitian tersebut menunjukan bahwa terjadi penurunan skor mual muntah pada ibu hamil trimester pertama karena terapi Asmaul Husna yang diberikan dapat memberi ketenangan dan kenyaman pada tubuh yang diperlukan untuk menurunkan hormon estrogen dan hormon progesterone (Soejoenes, 2014). Sejalan dengan penelitian diatas menurut Putri dkk (2018), menyatakan Asmaul Husna dapat memberikan rasa nyaman pada ibu hamil yang mengalami 
mual muntah mendapatkan rangsangan dari luar dan bekerja memproduksi zat kimia berupa neuropeptida yang akan diserap di dalam tubuh sehingga dapat memberi kenyaman pada pasien mual muntah pada ibu hamil trimester pertama. Menurut Silverrthon, (2013), Asamaul Husna yang bertugas menghambat aliran impuls dari neuron satu menuju neuron yang lain oleh neurotransmitter dimana sebagai siklus mual muntah pada ibu hamil dapat menenangkan suasana hati lebih tenang. Menurut peneliti terjadinya penurunan skor mual muntah pada ibu hamil di trimester pertaman dikarenakan adanya pemberian intervensi terapi Asmaul Husna yang dilakukan secara terus menerus selama 7 hari. Yang mengalami kenaikan mual muntah trimester pertaman adanya faktor kecemasan kemungkin berasal dari meningkatnya kadar hormonestrogen yang mengakibatkan mual muntah terjadi,setelah pemberian terapi Asmaul Husna mampu memberikan efek ketenangan dan kenyamanan dalam tubuh yang dapat menurunkan hormon estrogen dan hormon progesteron.

\section{Analisa Bivariat}

Analisa bivariat dalam penelitian ini untuk mengidentifikasi pengaruh terapi mendengarkan Asmaul Husna terhadap mual muntah pada ibu hamil trimester pertama di Puskesmas Sidoarjo Sragen. Hasil penelitian menggunakan uji wilcoxon seperti tabel 4.

Dalam penelitian ini pemberian terapi Amaul Husna selama 7 hari dengan durasi 15 menit sebanyak sekali sehari setiap petang mampu menurunkan mual muntah pada ibu hamil di trimester pertama. Hal ini ditunjukkan berdasarkan hasil uji statistik pada penelitian dimana skor mual muntah (pretest) dilakukan pemberian terapi Asmaul Husna memiliki skor mual muntah berat (7-10), sedangkan skor mual muntah sesudah (posttest) dilakukan pemberian terapi Asmaul Husna memiliki skor sedang (4-6) sebanyak 8 responden. Sedangkan berdasarkan uji Wilcoxon menunjukan nilai $P$ value $=0,000$ sehingga $P$ value $<0,05$ maka H0 di tolak dan Ha di terima bahwa terdapat pengaruh terapi mendengarkan Asmaul Husna terhadap mual muntah pada ibu hamil trimester pertama. Mual muntah akibat dari meningkatnya kadar estrogen, oleh karena keluhan ini terjadi pada trimester pertama. Pengaruh fisiologis hormon estrogen ini tidak jelas, mungkin berasal dari sistem saraf pusat atau akibat berkurangnya pengosongan lambung, setelah pemberian Asamul Husna skor mual muntah dapat menurun karena saat mendengarkan Amaul Husna (Soejoenes, 2014). Rasa nyaman pada ibu hamil tersebut dapat mempengaruhi hormon estrogen dan hal yang dapat berpengaruh menurunkan mual muntah pada ibu hamil (Soejoenes, 2014). 
Hal ini didukung oleh pendapat (Ariani, 2015) mememukakan bahwa lantunan Asmaul Husna dapat memberikan rangsangan pasa saraf simpatik dan saraf parasimptik untuk menghsilkan respon relaksasi yang menciptakan suasana rileks dan menyenangkan sehinga merangsang pelepasan zat kimia gamma amino butytric acid (GABA), enkefanin dan beta endorphin yang dapat mengeliminasi neurotransmitter rasa nyeri sehingga meciptakan ketenangan dan memperbaiki suasana hati pasien.

Menurut peneliti penurunan mual muntah pada ibu hamil di terimester pertama pada responden penelitian ini selain karena Asmaul Husna memberi efek kenyaman dan ketenangan dalam tubuh juga didukung oleh responden penelitian yang sangat aktif dan koperatif dalam mengikuti penelitian, adanya keyakinan terhadap diri responden bahwa Asmaul Husna benar-benar mampu menurunkan mual muntah pada ibu hamil di terimester pertama menjadi dorongan sendiri kepada responden untuk selalu memperhatikan pola hidup keseharianya mulai dari pola makan, aktifitas dan istirahatnya. Hal ini serta adanya dukungan dari keluarga responden yang selalu mendukung disetiap peneliti melakukan intervensi dan observasi kepada responden. Selain terjadi penurunan mual muntah pada ibu hamil di trimester pertama skor mual muntah naik dikarenakan hormon estrogen naik maka terjadinya mual muntah ibu hamil di trimester petama.

\section{KESIMPULAN DAN SARAN}

Mayoritas usia responden yaitu berusia 26-35 tahun sebanyak 9 responden (56,3\%).

Sekor mual muntah sebelum dilakukan terapi Asmaul Husnaresponden mengalami mual muntah berat sebanyak 16 responden (100\%).

Skor mual muntah setelah dilakukan terapi Asmaul Husna responden mual muntah ringan dan sedang memiliki jumlah yang sama sebanyak 8 responden (50\%).

Terdapat pengaruh terapi Asmaul Husna terhadap penurunan mual muntah pada ibu hamil di trimester pertama di wilayah kerja puskesmas Sidoharjo, Sragen sebelum dan sesudah dilakukan terapi dengan $P$ value $<0,05$.

Penelitian ini dapat dijadikan pengalaman yang bermanfaat bagi peneliti dalam mengatasi mual muntah pada ibu hamil di trimester pertama sebagai referensi tindakan terapi selain pemberian obat.

\section{UCAPAN TERIMAKASIH}

1. Puji syukur kehadirat Allah SWT karena penulis telah menyelesaikan penyusunan artikel hingga selesai. 
2. Civitas akademika Fakultas Ilmu Kesehatan Universitas kusuma husada atas support dan kerjasamanya.

3. LPPM Panti Waluya yang memberikan kesempatan penulis untuk mempublikasikan artikel ini.

4. Ibu hamil trimester pertama yang telah bersedia menjadi responden hingga penelitian selesai dan diterbitkan pada jurnal.

5. Keluarga yang memberikan support serta doa yang tulus.

6. Seluruh pihak yang tidak dapat penulis sebutkan satu per satu yang membantu penulis melewati proses penyusunan jurnal ini.

\section{DAFTAR PUSTAKA}

Ariani. (2015). Stop Kanker. Penerbit : Istana Media.

Badan Pusat Statistik. (2017). Badan Pusat Statistik Tabel Dinamis. Diambil kembali dari Badan Pusat

Statistik: https://www.bps.go.id/site/resultTab

Depkes RI. (2017). Riset Kesehatan Dasar. Jakarta: Badan Penelitian dan Pengembangan Kesehatan Kementrian Kesehatan RI.

Fatmawati. (2012). Ilmu Kebidanan. Jakarta: Yayasan Bina Pustaka Sarwono Prawirohardjo.

Hackar. (2012). Konsep Mual Pada Ibu Primigravida Trimester I. Jakarta: Salemba Medika.

Lukman. (2012). Aliran Pemikiran Pendidikan Islam. Jakarta: PT. Raja Grafindo Persada.

Marunung. (2011). Buku ajar keperawatan maternitas asuhan keperawatan intranatal. Jakarta : Trans Info Media.

Omoigui. (2014). Ilmu kebidanan: Patologi dan fisiologi persalinan human labor and birth edisi $1 \&$ 2. Yogyakarta: Yayasan Essentia Medica.

Perry \& Potter. (2013). Fundamental of nursing. Jakarta: Kedokteran EGC.

Putri, dkk. (2018). Konsep Kebidanan berdasarkan kajian filosofi dan sejarah forum ilmu dan kesehatan.

Sitoru (2012). Manajemen Keperawatan: Manajemen Keperawatan di Ruang Rawat, Jakarta: Sagung Seto.

Soejoenes (2014). Faktor-faktor Yang Mempengaruhi Sikap Ibu Primigravida Dalam Mengurangi Mual Muntah Pada Kehamilan Trimester Pertama Di Wilayah Puskesmas Kendalsari

Kecamatan Lowokwaru Malang. Diakses tanggal 16 Desember 2018.

Sukartiningsih. (2012). Metode Penelitian faktor umur. Bandung: PT Remaja Rosdakarya.

Swarihandayanti. (2014). Pengaruh terapi murrottal terhadap pasien nyeri Terhadap Keluhan Mual

Muntah Pada Pasien Post Kemoterapi di RSUD kraton kabupaten pekalongan Diakses pada

03 November 2018.

Tiran (2015). Seri Asuhan Kebidanan Mual dan Muntah Kehamilan. Jakarta : EGC.

Trottier (2012). Gejala mual muntah pada yang di alami oleh ibu hamil. Jakarta : EGC

Tuner (2013). Nursing: Memahami Berbagai Macam Penyakit. Alih Bahasa Paramita. Jakarta : PT. Indek. 


\section{LAMPIRAN}

Tabel 1 Karakteristik Responden Berdasarkan Usia $(\mathbf{n}=16)$

\begin{tabular}{ccc}
\hline Usia & f & \% \\
\hline $17-25$ tahun & 5 & 31,3 \\
$26-35$ tahun & 9 & 56,3 \\
$36-45$ tahun & 2 & 12,5 \\
\hline Total & 16 & 100 \\
\hline
\end{tabular}

Tabel 2 Distribusi Frekuensi Mual Muntah Sebelum Mendengarkan Asmaul Husna (n=16) Mual Muntah $\%$

Sebelum

\begin{tabular}{lll}
\hline Mual muntah berat & 16 & 100 \\
\hline Total & 16 & 100
\end{tabular}

Tabel 3 Distribusi Frekuensi Mual Muntah Sesudah Mendengarkan Asmaul Husna (n=16)

\begin{tabular}{lcc}
\hline $\begin{array}{l}\text { Mual Muntah } \\
\text { Sesudah }\end{array}$ & F & \% \\
\hline Mual muntah ringan & 8 & 50 \\
Mual muntah sedang & 8 & 50 \\
\hline \multicolumn{1}{c}{ Total } & 16 & 100 \\
\hline
\end{tabular}

Tabel 4 Analisa Uji Wilcoxon $(n=16)$

\begin{tabular}{|c|c|c|c|c|c|c|}
\hline \multirow[t]{2}{*}{ Variabel } & \multicolumn{6}{|c|}{ Mual muntah sesudah } \\
\hline & & Ringan & Sedang & Total & Z & p-value \\
\hline $\begin{array}{l}\text { Mual } \\
\text { muntah } \\
\text { sebelum }\end{array}$ & Berat & $8(50 \%)$ & $8(50 \%)$ & $16(100 \%)$ & $-3,570$ & 0,000 \\
\hline Total & & $8(50 \% \%)$ & $8(50 \%)$ & $16(100 \%)$ & & \\
\hline
\end{tabular}

